ISSN 0258-7122

Bangladesh J. Agril. Res. 34(2) : 279-285, June 2009

\title{
RESPONSE OF NITROGEN AND PLANT SPACING OF TRANSPLANTED AMAN RICE
}

\author{
K. M. SALAHUDDIN ${ }^{1}$, S. H. CHOWHDURY ${ }^{2}$, S. MUNIRA ${ }^{3}$ \\ M. M. ISLAM ${ }^{4}$ AND S. PARVIN ${ }^{5}$
}

\begin{abstract}
An experiment was conducted during July-December 2001 at the Agronomy field laboratory, Bangladesh Agricultural University, Mymensingh to study the effect of nitrogen levels and plant spacing on the yield and yield contributing characters of transplant Aman rice (var. BRRI Dhan 31). Five levels of nitrogen $(0,50,100,150,200 \mathrm{~kg} \mathrm{~N} / \mathrm{ha})$ and three spacings $(25 \mathrm{~cm} \times 20 \mathrm{~cm}, 25 \mathrm{~cm} \times 15$ $\mathrm{cm}, 25 \mathrm{~cm} \times 10 \mathrm{~cm}$ ) were included as treatment variables. A gradual increase in panicle length $(24.50 \mathrm{~cm})$, grains/panicle 110$)$ and grain yield (4.91 t/ha) were observed with the increase in nitrogen levels upto $150 \mathrm{~kg} / \mathrm{ha}$ and declined thereafter. Thousand-grain weight was not significantly influenced by application of different levels of nitrogen. The maximum grain yield (4.22 t/ha) was observed at the spacing $25 \mathrm{~cm}$ x $10 \mathrm{~cm}$ closely followed by $25 \mathrm{~cm}$ x $15 \mathrm{~cm}$ $(4.21 \mathrm{t} / \mathrm{ha})$. Wider spacing $(25 \mathrm{~cm} \times 10 \mathrm{~cm})$ produced the tallest plant $(108.38$ $\mathrm{cm})$, but significantly highest tllers/hill (8.06) and grains/panicle was recorded from $(25 \mathrm{~cm}$ x $20 \mathrm{~cm})$. Plant spacing had also no significant effect on 1000-grain weight. The interaction effects of nitrogen and plant spacing was significant in panicle length, grains/panicle, and grain yield. The higher grain yield (5.00 t/ha) was recorded from the treatment combination of $150 \mathrm{~kg}$ N/ha with $25 \mathrm{~cm} \mathrm{x} 15$ $\mathrm{cm}$ spacing, but statistically identical to same $\mathrm{N}$ dose with other two spacings. Response of grain yield to added $\mathrm{N}$ was quadratic. The optimum doses were found to be $132 \mathrm{~kg} \mathrm{~N} / \mathrm{ha}$ for $25 \mathrm{~cm} \mathrm{x} 20 \mathrm{~cm}, 119 \mathrm{~kg} \mathrm{~N} / \mathrm{ha}$ for $25 \mathrm{~cm}$, and $177 \mathrm{~kg}$ $\mathrm{N} /$ ha for $25 \mathrm{~cm} \mathrm{x} 10 \mathrm{~cm}$ spacing, yielding 4.38, 4.63 and 4.75 t/ha, respectively.
\end{abstract}

Key Words : Nitrogen, plant spacing, aman rice.

\section{Introduction}

Bangladesh grows rice (Oryza sativa L.) as a main foodgrain crop. It is grown in more than hundred countries of the owrld and is the staple food for $60 \%$ of the world population (Khush and Chowdhury, 1991). It provides about $70 \%$ of the calories consumed by 130 million people of Bangladesh. It constitutes about $90 \%$ of foodgrains and covers about $80 \%$ of total cropped area of the country (AIS, 1996). However, the potential for increasing rice production strongly depends on the ability to integrate a better crop management for the different varieties into existing cultivation systems (Mikkelsen et al., 1995). A higher output unit area also demands considerable amounts of external inputs, such as fertilizers.

\footnotetext{
${ }^{1}$ Assistant Editor, BARI, Gazipur, ${ }^{2}$ Professor, Dept. of Agronomy, BAU, Mymensingh, ${ }^{3}$ Lecturer, SAU, Dhaka, ${ }^{4}$ Lecturer, BSMRAU, Gazipur and ${ }^{5}$ Scientific Officer (T\&C), BARI, Gazipur, Bangladesh.
} 
Nitrogen is the most essential element in determining the yiedl potential of rice and nitrognous fertilizer is one of the major inputs to rice production (Mae, 1997). Almost every farmer has tendency to apply costly $\mathrm{N}$ fertilizer exces to get a desirable yield of Aman rice (Saleque et al., 2004), but imbalance use of $\mathrm{N}$ fertlizer causes harm to the crop and decreases grain yield.

Plant spacing is an another important factor, which plays a significant role on growth, development, and yield of rice at its optimum level beside it, which provides scope to the plants for efficient utilization of solar radiation and nutrients (Miah et al., 1990). Closer spacing hampers intercultural operations and as such more competition arises among the plants for nutrients, air, and light. As a result, plant becomes weaker, thinner and consequently reduces yield. Under closer plant spacing, farmers can not get desired hills/unit area which also ultimately reduces yield. Therfore, proper manipulation of planting density may lead to increase the economic yield of T. Aman rice. The present investigation was carried out to investigate the yield response of $\mathrm{T}$. Aman rice in relation to nitrogen levels and plant spacing

\section{Materials and Method}

The experiment was conducted at the Agronomy Field Laboratory, Bangladesh Agricultural University, Mymensingh during the period from July to December 2001. The soil of the experimental field was silty loam in texture and slightly acidic in reaction ( $\mathrm{pH} 6.5$ ) with low organic matter content (1.23\%). The total nitrogen, available phosphorus, available sulphur, and exchangeable potassium were $0.129 \%, 13.2 \mathrm{ppm}, 16 \mathrm{ppm}$, and $0.22 \mathrm{meq} / 100 \mathrm{~g}$ soil. The total rainfall during the crop season was $989 \mathrm{~mm}$ and the maximum and minimum air mean temperature recorded 30.6 and $22.7^{\circ} \mathrm{C}$, respectively.

The treatments comprised of five levels of nitrogen (0, 50, 100, 150 and, 200 $\mathrm{kg} \mathrm{N} / \mathrm{ha}$ ) and three plant spacings $(25 \mathrm{~cm} \times 20 \mathrm{~cm}, 25 \mathrm{~cm} \times 15 \mathrm{~cm}$, and $25 \mathrm{~cm} \times$ $10 \mathrm{~cm}$ ). The experiment was laid out in a factorial randomized complete block design with three replications. The size of unit plot was $4.0 \mathrm{~m}$ x $2.5 \mathrm{~m}$. Rice seeds (var. BRRI dhan 21) were raised in well prepared seed bed. Before raising seeds in the nursery, seeds were water soaked for 24 hours and these were kept in jute bags in dark conditions. After sprouting, the seeds were sown in wet seed bed on 19 July 2001. Thirty-five day old seedlings were uprooted carefully from the nursery and transplanted (2-3 seedlings/hill) on the well puddled experimental plots on 6 August 2001. Fertilizers were applied @ 100, 70, 60, and $10 \mathrm{~kg} / \mathrm{ha}$ of $\mathrm{P}, \mathrm{K}, \mathrm{S}$, and Zn through triple super phosphate (TSP), muriate of potash (MoP), gypsum, and zinc sulphate $\left(\mathrm{ZnSO}_{4}\right)$. The whole amount of TSP, MoP, gypsum, and $\mathrm{ZnSO}_{4}$ were applied at the time of final land preparation. The whole amount of urea was top-drssed in 3 equal instalments at 15, 30, and 50 days after transplants. Irrigation along with other intercultural operations were done as and 
when required. The crop of individual plots were separately harvested at full maturity on 20 November 2001. Data on plant height, number of total and effective tillers/hill, panicle length, number of grains/panicle, and weight of 1000 -grain were collected from five sample plants of each plot. The grain weight for each plot were recorded after proper drying in sun. The collected data were statistically analyzed and mean differences was compared by Duncan's New Multiple Range Test (DMRT).

\section{Results and Discussion}

Results of the present study regarding the influence of nitrogen levels and plant spacing and their interactions on the yield and yield components of transplanted Aman rice have been presented in Table 1 and 2 .

Effect of nitrogen: Plant height, number of effective tillers/hill, panicle length, grains/panicle, 1000-grain weight, and grain yield/ha were significantly, influenced by different levels of nitrogen. Thousand grain weight remained unaltered due to $\mathrm{N}$ fertilizer application (Table 1). Plant height increased with the increasing rates of nitrogen upto $200 \mathrm{~kg} / \mathrm{ha}$ and it was found significantly higher from the other levels of nitrogen. The shortest plant $(100.72 \mathrm{~cm})$ was found in the control plot (without $\mathrm{N}$ ). Nitrogen induced maximum vegetative growth with higher rates of N. Similar results were also reported by Navin et al. (1996). Number of effective tillers/hill followed a pattern similar to that obtained for plant height. Panicle length increased with the increase of nitrogen rate upto 150 $\mathrm{kg} \mathrm{N} / \mathrm{ha}$ and thereafter declined. The longest panicle $(24.50 \mathrm{~cm})$ was observed when $150 \mathrm{~kg} \mathrm{~N} / \mathrm{ha}$ was applied and the shortest $(18.15 \mathrm{~cm})$ from control. Nitrogen nutrient takes part in panicle formation as well as panicle elongation and for this reason, panicle length increased with the increase of $\mathrm{N}$-fertilization upto $150 \mathrm{~kg} / \mathrm{ha}$. The highest number of grains/panicle (109.79) was obtained at $150 \mathrm{~kg} / \mathrm{ha}$, which was significantly different from other $\mathrm{N}$ levels. Nitrogen helped in proper filling of seeds which resulted higher produced plump seeds and thus the number of grains/panicle. The lowest number of grains/panicle (99.41) was obtained from $0 \mathrm{~kg} \mathrm{~N} / \mathrm{ha}$.

Grain yield of T. Aman rice increased gradually with the increasing levels of nitrogen upto $150 \mathrm{~kg} \mathrm{~N} / \mathrm{ha}$, but at higher rates (200 kg/ha), grain yield tended to decrease. The highest grain yield (4.91 t/ha) was obtained at $150 \mathrm{~kg} \mathrm{~N} / \mathrm{ha}$ and the lowest (3.31 t/ha) from $0 \mathrm{~kg} \mathrm{~N} / \mathrm{ha}$. Similar trend was also observed by Haider et al. (1988). The yield difference between the highest and the lowest yielding treatments was $48 \%$. The yield advantage of $\mathrm{N}$ application upto $150 \mathrm{~kg} / \mathrm{ha}$ was mainly due to improvement of yield components viz., panicle length and number of grains/panicle. Response function, established from the yield and $\mathrm{N}$ data was quadratic in nature according to the equation $\mathrm{Y}=\mathrm{a}+\mathrm{bx}+\mathrm{cx}^{2}$. The common equation for all $\mathrm{N}$ obtained was $\mathrm{y}=3.174+0.022 \mathrm{x}-0.0007 \mathrm{x}^{2}$. The co-efficient of 
determination $\left(\mathrm{R}^{2}\right)$ indicating that $85 \%$ of the total variation in the yield can be attributed to the variation in $\mathrm{N}$ alone.

Effect of plant spacing: Plant spacing significantly influenced the plant height, number of effective tillers/hill, panicle length, grains/ panicle, and grain yield/ha. Plant spacing did not show any significant variation in respect of 1000-grain weight (Table 1). Sparsely populated plants $(25 \mathrm{~cm} \times 20 \mathrm{~cm})$ were the tallest and the shortest from densely populated plants. Plant height at $25 \mathrm{~cm} \times 15 \mathrm{~cm}$ and 25 $\mathrm{cm}$ x $10 \mathrm{~cm}$ spacing were statistically identical. Number of effective tillers/hill was significantly highest (8.06) at the spacing of $25 \mathrm{~cm} \mathrm{x} 15 \mathrm{~cm}$. The lowest (7.48) effective tillers/hill was obtained at $25 \mathrm{~cm} \times 20 \mathrm{~cm}$ spacing, which was statistically identical with $25 \mathrm{~cm} \times 10 \mathrm{~cm}$. Plant spacing had also significant effect on panicle length. Longest panicle $(21.62 \mathrm{~cm})$ was observed at $25 \mathrm{~cm} \times 15$ $\mathrm{cm}$ spacing and it was statistically identical with $25 \mathrm{~cm} \times 10 \mathrm{~cm}$ spacing. The shortest panicle $(20.44 \mathrm{~cm})$ was observed from $25 \mathrm{~cm}$ x $20 \mathrm{~cm}$ spacing. Number of grains/panicle decreased with closer and wider spacing did not vary and were at par. However, the highest grains/panicle (106.11) was observed from the spacing $25 \mathrm{~cm} \times 15 \mathrm{~cm}$. Plant spacing had significant effect on grain yield/ha (Table 1). Grain yield increased from 3.90 t/ha to 4.22 t/ha with the decrease in plant spacing. Higher grain yield (4.22 t/ha) was obtained at closer spacing $(25 \mathrm{~cm} \mathrm{x}$ $10 \mathrm{~cm})$ followed by $25 \mathrm{~cm} \times 15 \mathrm{~cm}(4.21 \mathrm{t} / \mathrm{ha})$ and the lowest $(3.90 \mathrm{t} / \mathrm{ha})$ from 25 $\mathrm{cm} \times 20 \mathrm{~cm}$. The contribution of closer spacing for higher yield was strongly supported by Azad et al. (1995), Padmajarao (1995) and Islam et al. (1994). The increase in grain yield with increasing plant spacing upto $25 \mathrm{~cm} \mathrm{x} 15 \mathrm{~cm}$ might be attributed to higher number effective tillers/hill and grains/pancle.

Table 1. Effect of nitrogen and plant spacing on the yield and yield components of transplanted Aman rice (Mymensingh, 2001).

\begin{tabular}{|c|c|c|c|c|c|c|}
\hline Treatment & $\begin{array}{c}\text { Plant } \\
\text { height }(\mathrm{cm})\end{array}$ & $\begin{array}{l}\text { Effective } \\
\text { tillers/hill } \\
\text { (no.) }\end{array}$ & $\begin{array}{c}\text { Panicle } \\
\text { length }(\mathrm{cm})\end{array}$ & $\begin{array}{c}\text { Grains/ } \\
\text { panicle } \\
\text { (no.) }\end{array}$ & $\begin{array}{c}\text { Wt of } \\
\text { 1000-grain } \\
\text { (g) }\end{array}$ & $\begin{array}{c}\text { Grain yield } \\
\text { (t/ha) }\end{array}$ \\
\hline \multicolumn{7}{|c|}{$\underline{N}$ level (kg/ha) } \\
\hline 0 & $100.72 \mathrm{e}$ & 5.90e & $18.15 \mathrm{e}$ & $99.41 \mathrm{e}$ & 23.90 & 3.31d \\
\hline 50 & $103.50 \mathrm{~d}$ & 6.54d & $19.65 d$ & 102.54d & 26.41 & $3.75 \mathrm{c}$ \\
\hline 100 & $105.45 c$ & $7.55 c$ & $22.45 \mathrm{~b}$ & $107.38 b$ & 24.60 & $4.41 \mathrm{~b}$ \\
\hline 150 & $109.13 b$ & $8.92 \mathrm{~b}$ & $24.50 \mathrm{a}$ & 109.79a & 25.32 & $4.91 \mathrm{a}$ \\
\hline 200 & 112.98a & $9.61 \mathrm{a}$ & $20.95 c$ & $104.05 c$ & 24.96 & $4.17 \mathrm{bc}$ \\
\hline CV (\%) & 1.27 & 3.65 & 2.38 & 3.63 & 4.65 & 8.06 \\
\hline \multicolumn{7}{|c|}{ Plant spacing $(\mathrm{cm})$} \\
\hline $25 \times 20$ & $108.38 \mathrm{a}$ & $7.48 \mathrm{~b}$ & $20.44 b$ & $103.57 b$ & 24.81 & $3.90 \mathrm{~b}$ \\
\hline $25 \times 15$ & $106.10 \mathrm{~b}$ & $8.06 a$ & $21.62 \mathrm{a}$ & 106.11a & 24.92 & $4.21 \mathrm{a}$ \\
\hline $25 \times 10$ & $104.58 \mathrm{~b}$ & $7.57 \mathrm{~b}$ & $21.36 \mathrm{a}$ & $104.23 b$ & 25.38 & $4.22 \mathrm{ab}$ \\
\hline CV (\%) & 1.27 & 3.56 & 3.28 & 3.63 & 4.65 & 8.06 \\
\hline
\end{tabular}


Interaction effect of nitrogen and plant spacing: Interaction of plant spacing and nitrogen levels showed significant influence on panicle length, number of grains/panicle, and grain yield/ha. Plant height, number of effective tillers/hill, and 1000-grain weight were not found significant due to plant spacing and nitrogen fertilizer. From Table 2, it was evident that significantly the longest panicle (25.39 $\mathrm{cm}$ ) was obtained from $25 \mathrm{~cm} \mathrm{x} 15 \mathrm{~cm}$ with $150 \mathrm{~kg} \mathrm{~N} / \mathrm{ha}$ and it was statistically identical with spacing $25 \mathrm{~cm} \mathrm{x} 10 \mathrm{~cm}(24.60 \mathrm{~cm})$. Plants grown at any plant spacing without $\mathrm{N}$ fertilizer produced shortest panicle. The maximum number of grains/panicle (112.50) obtained by the treatment combination $25 \mathrm{~cm} \times 15 \mathrm{~cm}$ spacing with $150 \mathrm{~kg} \mathrm{~N} / \mathrm{ha}$, which was significantly higher than other treatment combinations. The lowest number of grains/panicle was given by $0 \mathrm{~kg} \mathrm{~N} / \mathrm{ha}$ irrespective of plant spacing. Grain yield/ha increased with increasing level of nitrogen upto $150 \mathrm{~kg} / \mathrm{ha}$ irrespective of plant spacing. The spacing $25 \mathrm{~cm} \times 15 \mathrm{~cm}$ accompanied with $150 \mathrm{~kg}$ $\mathrm{N} / \mathrm{ha}$ gave the highest yield (5.00 $\mathrm{t} / \mathrm{ha}$ ), but it was statistically to those of $\mathrm{N}$ dose with $25 \mathrm{~cm} \times 20 \mathrm{~cm}$ and $25 \mathrm{~cm} \times 10 \mathrm{~cm}$ spacing. Generally grain yields were less in control $\mathrm{N}$ treatment irrespective of plant spacing. Regression analysis was done to quantitfy the relationship between grain yield and applied nitrogen fertilizers irrespective of plant spacing (Fig. 1). The quadratic equation for each plant spacing obtained form the regression analysis was:

$\mathrm{y}=2.990+0.00008 \mathrm{x}^{2}, \mathrm{R}^{2}=0.75$ (for $25 \mathrm{~cm} \mathrm{x} 20 \mathrm{~cm}$ )

$\mathrm{y}=3.350+0.0215 \mathrm{x}-0.00009 \mathrm{x}^{2}, \mathrm{R}^{2}=0.84$ (for $25 \mathrm{~cm} \mathrm{x} 15 \mathrm{~cm}$ )

$\mathrm{y}=3.180+0.0177 \mathrm{x}-0.00005 \mathrm{x}^{2}, \mathrm{R}^{2}=0.93$ (for $25 \mathrm{~cm} \mathrm{x} 10 \mathrm{~cm}$ )

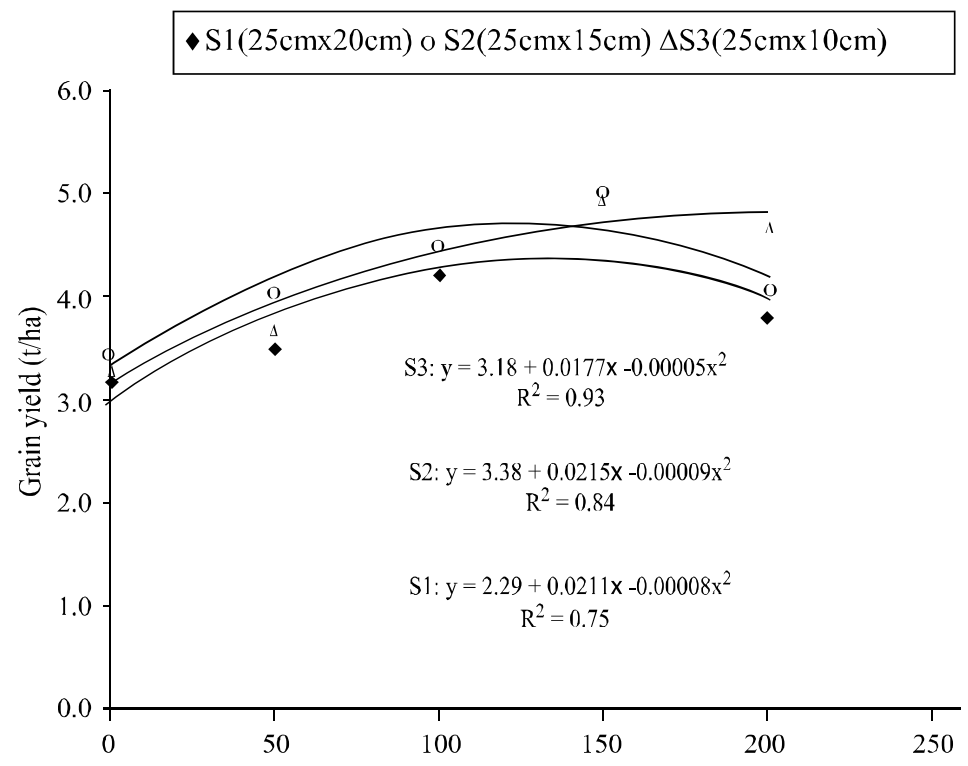

Fig. 1. Relationship between grain yield \& nitrogen level irrespective of plant spacing of T. anan rice. 
Table 2. Interaction effect of nitrogen levels and plant spacing on the yield and yield attributes of transplanted Aman rice.

\begin{tabular}{l|c|c|c|c|c|c|c}
\hline $\begin{array}{c}\text { N level } \\
(\mathrm{kg} / \mathrm{ha})\end{array}$ & $\begin{array}{c}\text { Spacing } \\
(\mathrm{cm})\end{array}$ & $\begin{array}{c}\text { Plant } \\
\text { height } \\
(\mathrm{cm})\end{array}$ & $\begin{array}{c}\text { No. of } \\
\text { effective } \\
\text { tillers/hill }\end{array}$ & $\begin{array}{c}\text { Panicle } \\
\text { length } \\
(\mathrm{cm})\end{array}$ & $\begin{array}{c}\text { No. of } \\
\text { grains/ } \\
\text { panile }\end{array}$ & $\begin{array}{c}\text { Wt of } \\
1000- \\
\text { grain }(\mathrm{g})\end{array}$ & $\begin{array}{c}\text { Grain } \\
\text { yield } \\
\text { (t/ha })\end{array}$ \\
\hline 0 & $25 \times 20$ & 102.53 & 5.80 & $18.10 \mathrm{ij}$ & $99.10 \mathrm{~g}$ & 21.86 & $3.18 \mathrm{f}$ \\
& $25 \times 15$ & 100.46 & 6.10 & $17.30 \mathrm{j}$ & $99.98 \mathrm{~g}$ & 25.15 & $3.45 \mathrm{f}$ \\
& $25 \times 10$ & 99.16 & 5.80 & $19.04 \mathrm{ij}$ & $99.15 \mathrm{~g}$ & 24.78 & $3.30 \mathrm{f}$ \\
\hline 50 & $25 \times 20$ & 104.56 & 6.34 & $18.84 \mathrm{ij}$ & $101.45 \mathrm{~b}$ & 26.06 & $3.51 \mathrm{ef}$ \\
& $25 \times 15$ & 103.66 & 7.00 & $20.44 \mathrm{fg}$ & $103.31 \mathrm{e}$ & 25.76 & $4.06 \mathrm{~d}$ \\
& $25 \times 10$ & 102.26 & 6.40 & $19.68 \mathrm{gh}$ & $102.87 \mathrm{e}$ & 27.42 & $3.68 \mathrm{e}$ \\
\hline 100 & $25 \times 20$ & 107.33 & 7.30 & $21.80 \mathrm{def}$ & $106.05 \mathrm{~cd}$ & 25.66 & $4.23 \mathrm{~cd}$ \\
& $25 \times 15$ & 105.40 & 7.90 & $23.11 \mathrm{~cd}$ & $109.50 \mathrm{~b}$ & 22.87 & $4.48 \mathrm{c}$ \\
& $25 \times 10$ & 103.63 & 7.40 & $22.44 \mathrm{cde}$ & $106.60 \mathrm{c}$ & 25.26 & $4.51 \mathrm{bc}$ \\
\hline 150 & $25 \times 20$ & 112.03 & 8.80 & $23.52 \mathrm{bc}$ & $108.31 \mathrm{~b}$ & 24.75 & $4.80 \mathrm{ab}$ \\
& $25 \times 15$ & 108.33 & 9.10 & $25.39 \mathrm{a}$ & $112.50 \mathrm{a}$ & 24.73 & $5.00 \mathrm{a}$ \\
& $25 \times 10$ & 107.03 & 8.80 & $24.60 \mathrm{ab}$ & $108.56 \mathrm{~b}$ & 26.48 & $4.95 \mathrm{ab}$ \\
\hline 200 & $25 \times 20$ & 115.46 & 9.20 & $14.46 \mathrm{gh}$ & $102.92 \mathrm{e}$ & 25.75 & $3.80 \mathrm{de}$ \\
& $25 \times 15$ & 112.66 & 10.10 & $21.84 \mathrm{de}$ & $105.25 \mathrm{~d}$ & 26.08 & $4.05 \mathrm{~d}$ \\
& $25 \times 10$ & 110.83 & 9.50 & $21.06 \mathrm{efg}$ & $103.98 \mathrm{e}$ & 23.05 & $4.68 \mathrm{ab}$ \\
\hline \multirow{2}{*}{ (\%) } & 1.27 & 1.27 & 3.6 & 3.28 & 3.63 & 4.65 & 8.06 \\
\hline
\end{tabular}

Mean values in a column having same or without letter(s) do not differ significantly at $5 \%$ level of probability.

The result indicated that the grain yield was increased with the increase of nitrogen application upto a certain limit irrespective of plant spacing. The value $\mathrm{R}^{2}$ (0.75 to 0.93 ) indicated that 75 to $93 \%$ of the total variation in grain yield at different spacings would be explained by the variation in applied nitrogen fertilizer. From these equations, the maximum estimated yield of $25 \mathrm{~cm} \mathrm{x} 20 \mathrm{~cm}$. $25 \mathrm{~cm} \mathrm{x} 15 \mathrm{~cm}$, and $25 \mathrm{~cm} \mathrm{x} 10 \mathrm{~cm}$ spacing were 4.38, 4.63, and $4.75 \mathrm{t} / \mathrm{ha}$ at 132.119 and $177 \mathrm{~kg} \mathrm{~N} / \mathrm{ha}$, respectively.

The result of the study realized that $150 \mathrm{~kg}$ t/ha with spacing $25 \mathrm{~cm} \mathrm{x} 15 \mathrm{~cm}$ gave higher grain yield (5.0 t/ha) but from regression analysis also showed similar result of same spacing with $119 \mathrm{~kg} / \mathrm{ha}$. So, optimum grain yield could be obtained from spacing $25 \mathrm{~cm}$ x $15 \mathrm{~cm}$ with $\mathrm{N}$ level varied from 119 to $150 \mathrm{~kg} / \mathrm{ha}$ depending upon soil fertility. 


\section{References}

ASI (Agricultural Information Service). 1996. Krishi Dairy. Agric. Int. Ser. Dhaka. p. 20-22.

Azad, A.K., M.A. Gaffer, S.C. Samanta, M.A. Kashem, and M.T. Islam 1995. Response of BR10 rice variety to different levels of nitrogen and spacing. Bangladesh J. Sci, Ind. Res. 30(1): 31-38.

Bhuiya, M.S.U., S.M.A. Hossain, and S.G. Kabir 1989. Nitrogen fertilization in rice Cv. BR10 after green manuring, Bangladesh J. Agril. Sci. 16(1): 89-92.

BRRI (Bangladesh Rice Research Institute). 1990. Adhunik Dhaner Chash (In Bangla) $6^{\text {th }}$ Edn. Booklet No. 5. Bangladesh Rice Res. Inst., Joydebpur, Gazipur. pp. 26-27.

Haider, M.R., Ali, M.I., S.M. Zaman, and A.F.S.M. Islam 1988. Yield and Yield attributes of rice as affected by $\mathrm{N}, \mathrm{P}, \mathrm{K}, \mathrm{S}$, and $\mathrm{Zz}$ fertilization. Bangladesh $\mathrm{J}$. Nuclear Agric. 4: 61-68.

Heenan, D.P. and P.E. Bacon. 1987. Effect of nitrogen fertilizer timing on crop growth and introgen use efficiency by different rice varieties in Southern Australia. In efficiency of nitrogen fertilizers on rice. International Rice Research Institute. Los Banos. Philippines. 97-105.

Islam, M.S., M.A.R. Sarker, M.S. Rahman, A.I.M. Musa, and S.C. Dhan. 1994. Effect of plant population density on transplant aus rice under tidally flooded conditions. Bangladesh J. Agril. Sci. 21(2): 349-353.

Khush, G.S. and R.C. Chowdhury 1991. Role of resistant varieties in integrated pexst management of rice. Food of Fert. Centre Extn., Taiwan, 162: 13.

Lious, T.M. 1987. Effect of spacing and fertilizer levels on changes of ear type in rice. J. Agril. China 140: 1-10.

Mae. T. 1997. Physiological nitrogen efficiency in rice. Nitrogen utilization. photosynthesis and yield potential. In plant nutrition for sustainable food production and environment. Ando T., K. Fujita, T. Mae. H. Matsumota, S. Mori and J. Sekiya (eds). Kluwer Academic Publishers Printed in Japan. 51-60.

Mandal, S.S., N.N. Sasmahapatra, and B.N. Chaterjee. 1987. Effect of high rates of potassium and nitrogen on rice yield components. Env. and Ecol. 5(2): 300-303.

Miah, M.H., M.A. Karim, M.S. Rahman, and M.S. Islam 1990. Performance of Nigersail mutants under different row spacings. Bangladesh J. Train. Dev. 3(2): 31-34.

Mikkelsen. D.S., G.R. Jayaweera and D.E. Rolston 1995. Nitrogen fertilization practices of low land rice culture. Nitrogen Fertilization in the Environment 171-223.

Navin, K., V.K. Singh, R.B. Thakur, and N. Kumar 1996. Effect of level and time of Napplication on the performance of winter rice. Journal of Applied Biology, Rejendra Agricultural University, Pusa, India, 6: 1-2, 48-53.

Padmajarao, S. 1995. Yield and high density grain as influenced by crop density and level in scented rice. Madras Agric. J. 82(2): 108-112.

Saleque. M.A., U.A. Naher N.N. Choudhury, and A.T.M.S. Hossain 2004. Variety specific nitrogen fertilizer recommendation for low land and rice. Commun. Soil Sci. Plant Anal. 35(13 \& 14): 189-1903. 